\title{
Identification of a mathematical model for a single- shaft power-generating GTE
}

\author{
Anatoly Tarelin', \\ Alexander Lyutikov', \\ Iryna Annopolska ${ }^{1}$ \\ ${ }^{1}$ A. Podgorny Institute of Problems \\ of Mechanical Engineering \\ NAS Ukraine in the city of Kharkiv, \\ Pozharskogo St. 2/10, \\ Kharkiv, Ukraine, 61046 \\ ${ }^{2}$ Gas Turbine Research \& Production \\ Complex "Zorya"-"Mashproekt" \\ Bogoyavlenskyy Ave, 42a, \\ Mykolaiv, Ukraine, 54018, \\ Email:lutikov.al@gmail.com
}

The design and development processes of gas turbine engines rely on the usage of mathematical models representing the physics of engine functioning processes. One way of increasing the validity of a mathematical model is its identification based on engine test results.

The identification of mathematical models of modern power-generating gas turbine engines (GTEs) presents a demanding and time-consuming task due to the necessity to identify the main controlled engine parameters determined in the course of experimental studies depending on a large number of the parameters that are not controlled during the experiment. In this regard the actual direction of reducing the labour intensity of the process of mathematical model identification is using identification program complexes. The object of the study was to solve the problem of structural-parametrical identification of the power-generating GTE functioning model detailing the turbine flow path calculations to the level of blade rows in order to obtain the GTE mathematical model that describes the characteristics of a real engine with given accuracy. To achieve the objective, the following problems were solved: variable parameters, controlled parameters and characteristics, ranges of their variations were selected from the total number of the mathematical model input data, the objective functions were defined; the task of the parametric identification according to the results of bench tests through GTE operating modes was performed; analytical approximating dependences for correcting coefficients (variable parameters) were obtained; structural-parametric identification of the mathematical model was performed. The novelty of the obtained results is the identification of the mathematical model of the nonlinear component GTE of the second level performed without model linearization (without its level lowering) by using the Optimum software packages. The methodological approach for the parametric identification of the mathematical model is proposed. This approach allows reducing the number of variable parameters under the modes lower that the maximum. It shows that the identified model allows obtaining the prediction results of the GTE parameters and characteristics through operating modes with a deviation of no more than $1.4 \%$ from the experimental data and, therefore, it will allow reduction of terms and an increase in the quality of power unit development.

Keywords: mathematical model, identification, gas turbine engines, variable parameters, controllable parameters 


\section{INTRODUCTION}

The design and development efficiency of gas turbine engines (GTEs) as well as the control of its technical state during operation is determined by the degree of adequacy and productivity of the mathematical models (MM) to be used at these stages. At the same time, the average MM of a particular engine type and an individual MM for a specific manufactured sample are distinguished. At the stage of development, individual MMs that take into account the constructional features of the specific engine are of interest. By means of an experimental simulation, the presence of such models makes it possible to define the influence of changes in the characteristics of the component under development on the engine parameters as a whole and to define the unit characteristics over the entire range of operating modes and environment conditions.

One of the ways of developing the individual MM of a specific GTE is identification of the design (a priori) MM on the engine bench test results.

The process of identification of MMs of modern power-generating GTEs is a very demanding task due to the necessity to identify the main controlled engine parameters (characteristics) (5 to 10 variables) determined in the course of experimental studies, depending on a great number of the parameters ( 30 to 50 variables) that are not controlled during the experiment, the values of which may vary in the process of identification. As such, the use of a software package (SP) for identification on the bench testing results that allows reducing labour intensity of specified processes, is a rather pressing task.

\section{OVERVIEW OF LITERATURE DATA}

Mathematical models of gas turbine engines differ by the modelling level depending on their purpose. The modelling level of the mathematical model is understood as the degree of depth and the fullness of relation among the inlet and outlet parameters. The following modelling levels can be assigned conditionally [1]:

- Level 0 - description of modelling object characteristics as "black box" using formal interrelations (tables, approximating and statistical dependences);
- Level 1 - application of the ratios and equations reflecting physical interrelations of internal subsystems with assumptions that are typical of engineering task statement; moreover, the subsystems are represented as zero-level models;

- Level 2 - detailed interrelations modelling of subsystems presented as first-level models in its turn.

As a whole, the level of GTE modelling should be effectually determined by the degree of detail adopted to describe components of the turbocompressor group. In the level 2 model, the mathematical models of the components of the turbocompressor group are detailed by stages and blade rows, i.e. represent as level 1 models. In this case, the gas flow through the grids of the blade rows is described with use of equations of gas dynamic that are based on the principles of conservation of mass, energy and momentum having regard to velocity triangles on a pitch diameter of every stage. For describing different types of losses in the grids the statistic and experimental data are used as encompassing dependences.

MMs of level 1 and level 2 are of great interest at the stage of GTE development. They describe GTE functioning processes with a higher accuracy degree. CAE technologies are widely used for modelling and identifying the GTE characteristics in the course of development. These technologies can be divided into two main groups.

The first group includes MMs implemented in such programs as SIMULINK/MATLAB and EcosimPro, which are not software packages of engine characteristics modelling but enable solving system of nonlinear equations belonging to the MMs of GTE. The following ones can be mentioned among them: Dymola (based on Modelica programming language) [2, 3], Simulink (integrated into the MATLAB environment) $[4,5]$, TRANSEO (based on the MATLAB environment) [6], PROOSIS (based on the EcosimPro system) [7] and others allowing the solution of a wide range of prediction tasks.

The second group includes specialized modelling systems - software packages (SP). In particular, in process of design and development of a GTE, the GASTURB [8, 9], GECAT [10], GSP [11], GRAD [12], ASTRA [13], and WebEngine [14] software packages are used. These complexes 
are characterized by great functionality: development of different static and dynamic MM of GTE configurations, investigation of throttle, climatic and external characteristics, and identification of MMs on bench test results.

Programs and SPs developed by branch design bureaus (BDB) and intended to be used within the objectives of the tasks of these enterprises should be noted in the second group. These are the programs specified in articles [15-17]. They are intended, in general, for calculating one fixed GTE configuration and take into account the operational peculiarities of the components included into the configuration under consideration, methodological and experimental experience of the $\mathrm{BDB}$ in this sphere to the fullest extent possible.

It should be noted that CFD prediction and its use are taken further by productivity growth. Ji et al. [18] present the first-level MM of a threeshaft GTE, the component characteristics of which are based on the results of CFD predictions performed in SP Numeca [19-21]. However, this approach does not take into account the inevitable spread of parameters during engine manufacturing, but it is an "ideal" design MM of the GTE. Taking into account the features of each particular GTE the CFD predictions are rather labour-intensive task.

So, the use of the second-level MM for describing a particular GTE operation is the most optimal variant in terms of information and computation speed. According to GTE bench tests results, the model identification is an effective method for the improvement of its accuracy.

Analysis of the listed SP of MM of GTE characteristics showed the absence of MM identification module according to test results for the most of them. In programs having such subsystems in their functionality, the identification of the MM is reduced to the model linearization (lowing its level due to the complexity of the level 2 models identification) and to the identification of task solution by the following methods: the least square method, the maximum likelihood method, the group method of data handling, equations, and others.

The main disadvantage of these methods is the likely significant deviations from actual estimates that are caused by the necessity for MM linearization of the investigated object. Consequently, they do not allow identification of a more informative level $2 \mathrm{MM}$ detailing prediction of a turbine flow path to the level of blade rows. Such specific is especially relevant for power-generating GTEs that are characterized by high values of turbine inlet temperature with intensive cooling of wheel space and with the necessity to take into account the influence of cooling air on the parameters in every turbine section.

Considering the above, identification of a non-linear component Level 2 mathematical model of prediction of thermo-gas-dynamical and thermo-technical characteristics of a power-generating GTE, which details the turbine flow path calculation to the level of blade rows without linearization, is a pressing challenge.

SP Optimum for optimization and identification of parameters and characteristics of power-generating plants is used for MM identification [22]. It allows carrying out prediction of identification criteria, parameters and characteristics of the object under study by the same levels as during GTE design without any model transformation, i.e. avoiding linearization.

\section{GOAL: SCOPE AND TASKS}

The objective of this research is to identify a structural-parametrical MM for a power-generating GTE detailing the turbine flow path calculation to the level of blade rows in order to obtain the GTE MM being adequate for experimental data. To achieve the objective, it is necessary to solve the following tasks:

- performing verification of a MM with bench tests results;

- selecting variable parameters from the total number of source data, controllable parameters and characteristics, ranges of their variations as well as to determine the objective functions;

- solving the problem of parametrical identification of a MM according to the results of bench tests through GTE operating modes;

- obtaining analytic approximating dependences for correcting coefficients (variable parameters);

- implementing the determined dependences into the structure of the MM. 


\section{EXPERIMENTAL DETERMINATION \\ OF THERMO-TECHNICAL \\ CHARACTERISTICS AND VERIFICATION OF THE MM}

The problem on identification of the MM was solved by the example of the MM of DO45 GTE developed and used at the SE GTRPC "Zorya"-"Mashproekt" [23]. As a part of the gas turbine power-generating plant GPP-60, its tests were carried out at the test bench with power output into the mains in accordance with the developed test program. This unit is developed for using primarily as a part of a combined-cycle plant (CCP) (gas steam units (GSU)). Two versions of configuration are considered: (1) CCP85 (one GPP-60 and one steam turbine K-25); (2) CCP-170 (two GPP-60 and one steam turbine K-50). The CCP data can be used both for newly built power plants and for modernizing the existing power plants and power units that have exhausted their performance potential.

Design parameters of GPP-60 in nominal mode are presented in Table 1.

To determine the thermo-technical characteristics of the engine during testing in all specified sections, the total flow parameters, as well
Table 1. Main parameters of GPP-60 at rated power mode [23]

\begin{tabular}{|c|c|}
\hline Power at generator terminals, MW & 60 \\
\hline $\begin{array}{l}\text { Efficiency factor related to the power at } \\
\text { electric generator terminals, } \%\end{array}$ & 37 \\
\hline $\begin{array}{l}\text { Fuel gas consumption }(100 \% \text { methane with } \\
\qquad \mathrm{LHV}=50050 \mathrm{~kJ} / \mathrm{kg}), \mathrm{kg} / \mathrm{h}\end{array}$ & 11670 \\
\hline Compressor pressure ratio & 18 \\
\hline Exhaust gas temperature, $\mathrm{K}$ & 793 \\
\hline Exhaust gas rate, $\mathrm{kg} / \mathrm{s}$ & 173.4 \\
\hline
\end{tabular}

as engine airflow, electric power and fuel gas consumption, were measured in accordance with the developed preparation scheme (Fig. 1).

After processing the test results, verification of the MM was conducted. Figure 2 shows the results of these comparisons for some parameters depending on the relative power $(\bar{N})$ (where $\bar{N}-$ the ratio of the current power (obtained during the tests) to the nominal design power of the engine) in the diagram form. The test analysis shows deviations of the obtained parameters from design values in the range $7-12 \%$. If it is explained by the feature of bench equipment for a part of them (bench gas conduit, flow-measuring collector that increase losses in the input device), the reasons of parameters deviation are ambiguous.

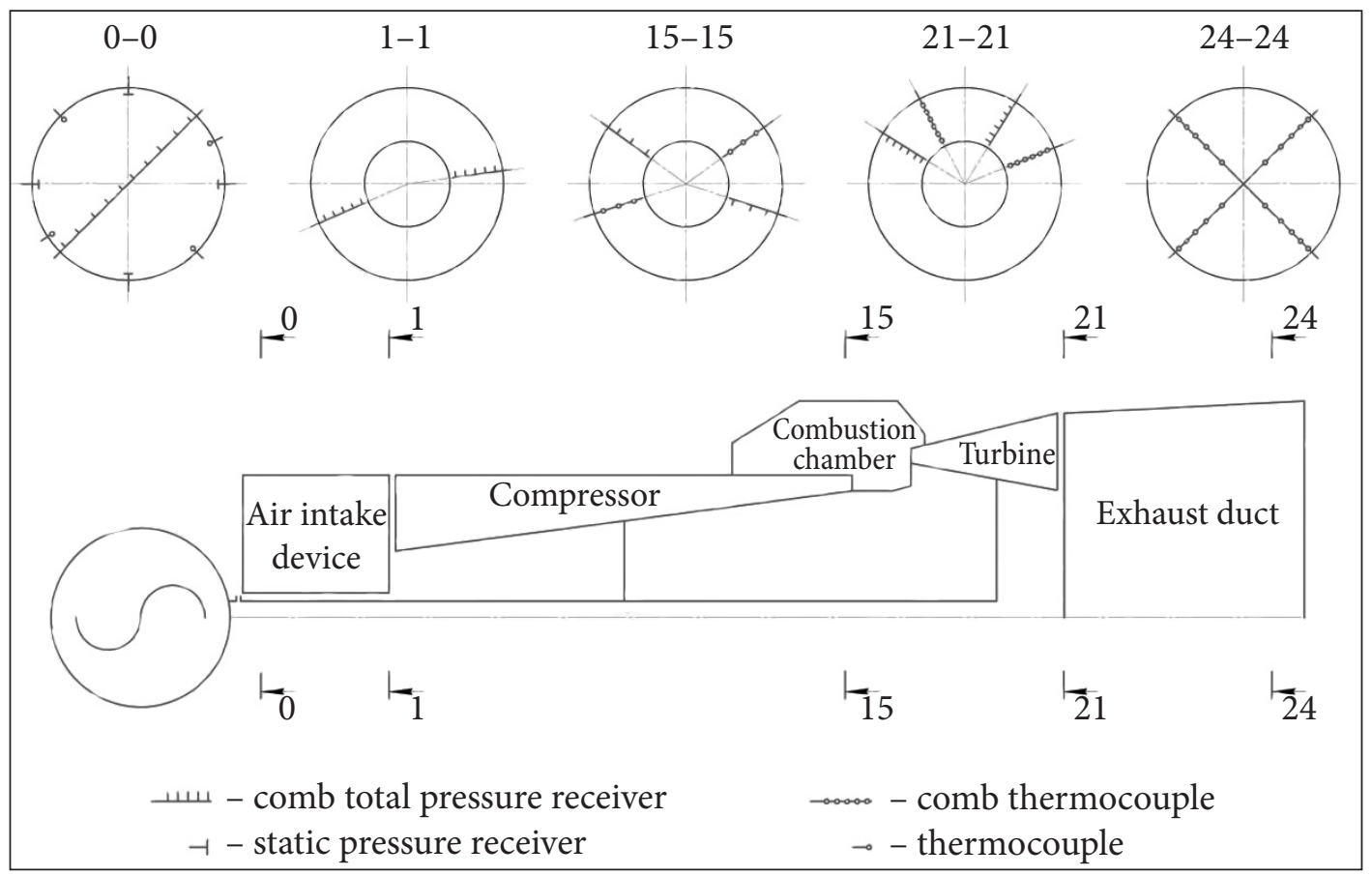

Fig. 1. Scheme of the preparation of the GTE at the test bench 


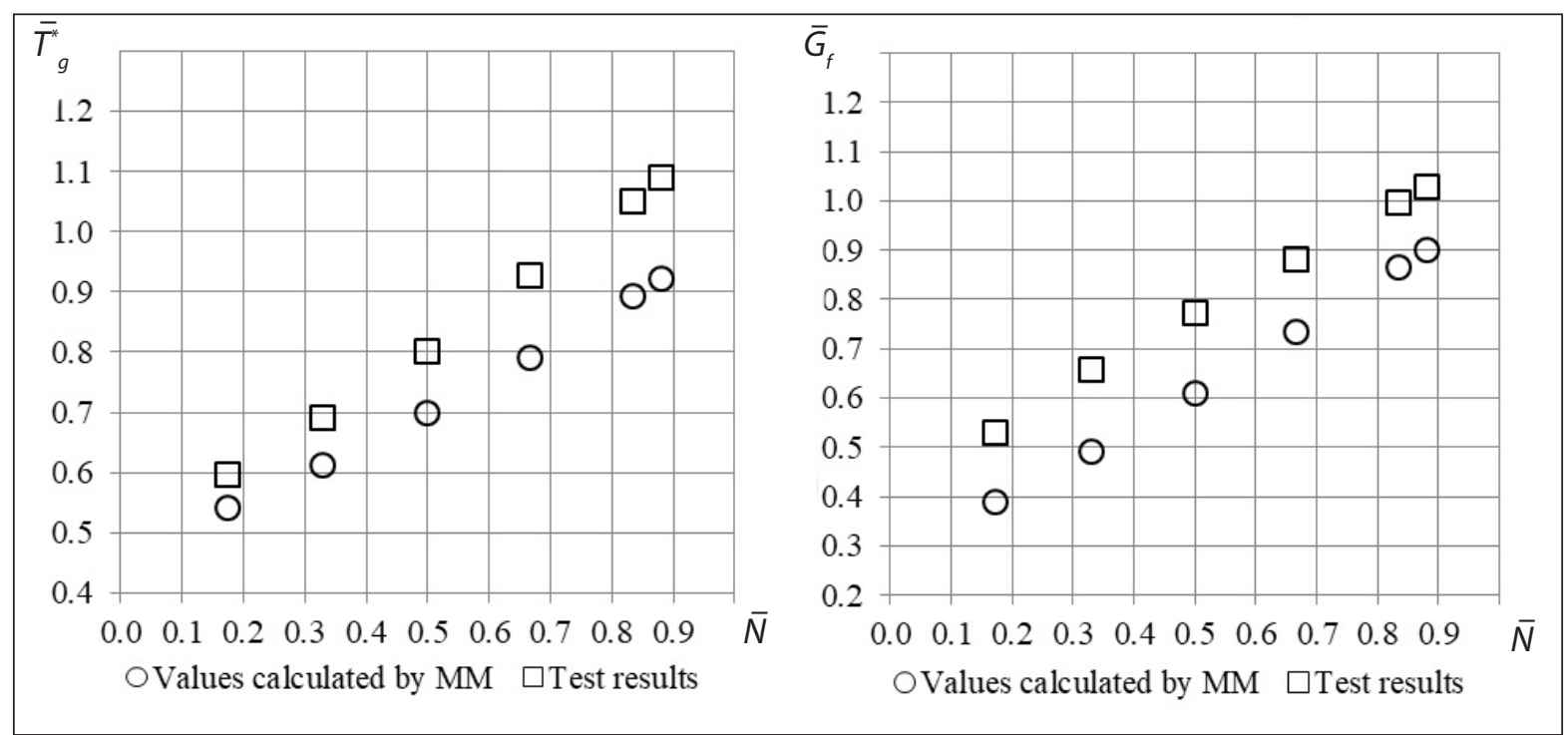

Fig. 2. a - GTE outlet gas temperature $\left(\bar{T}_{g}^{*}\right)$ dependence on power at the generator terminals $(\bar{N})$ in relative terms; $b$ - Fuel consumption $\left(\bar{G}_{f}\right)$ dependence on power at the generator terminals $(\bar{N})$ in relative terms

Such a mismatch in the results of calculated characterization is not acceptable at the development stage when it is necessary to determine the influence of changes in the characteristics of one component on the entire unit with high accuracy.

Thus, to obtain an adequate MM of the GTE test unit, it was decided to perform MM identification by experimental data.

In this case, the adequate model can be obtained by clarifying the input model parameters that were not measured during testing. That is, such a vector of input parameters is determined that enables obtaining the vector of model output parameters that maximally matches with the actual test results measured at the test bench.

\section{STATEMENT OF THE RESEARCH PROBLEM}

The identification of the MM by the test results is reduced to minimization of objective functions that represent discrepancy between the samenamed identification criteria obtained by MM and the engine experimental characteristics.

Herewith the identification criteria are subjected to restrictions that practically define the range of their variation.

Consequently, we have a multi-criteria problem of optimization with restrictions for the range of variations of identification criteria. Mathematically, with vector setting it is formulated as:

$$
\begin{aligned}
& F^{*}=F\left(X^{*}\right)=\min F(X) ; \\
& F=\left(f_{1}, f_{2}, 1 / 4, f_{m}\right) ; \\
& X=\left(x_{1}, x_{2}, 1 / 4, x_{n}\right) ; \\
& a_{i}<x_{i}<b_{i}, i=1,1 / 4, n ; \\
& c_{i}<f_{i}<d_{i}, i=1,1 / 4, m ; \\
& q_{i}(x) \geq 0, i=1,1 / 4, k ; \\
& h_{j}(x)=0, j=1,1 / 4, l,
\end{aligned}
$$

where $X$ is a vector of variable parameters;

$a_{i}, b_{i}$ are variation limits of variable parameters; $c_{i}, d_{i}$ are variation limits of objective functions; $q_{i}$ is inequation restrictions; $h_{j}$ is equation restrictions;

$n, m, k, l$ are the number of variable parameters, objective functions, inequation restrictions, equation restrictions, respectively;

$$
F^{*}=F\left(X^{*}\right)=\min F(X)=\left(\min f_{1}, \min f_{2}, 1 / 4, \min f_{m}\right)
$$
is the optimal value of the objective function;

$X^{*}$ is a vector of optimal parameters.

By the bench tests results the identification problem is solved for component non-linear MM of D045 GTE with a detailed prediction of a turbine flow path to the level of blade rows. Figure 3 presents a structure scheme of the model. 


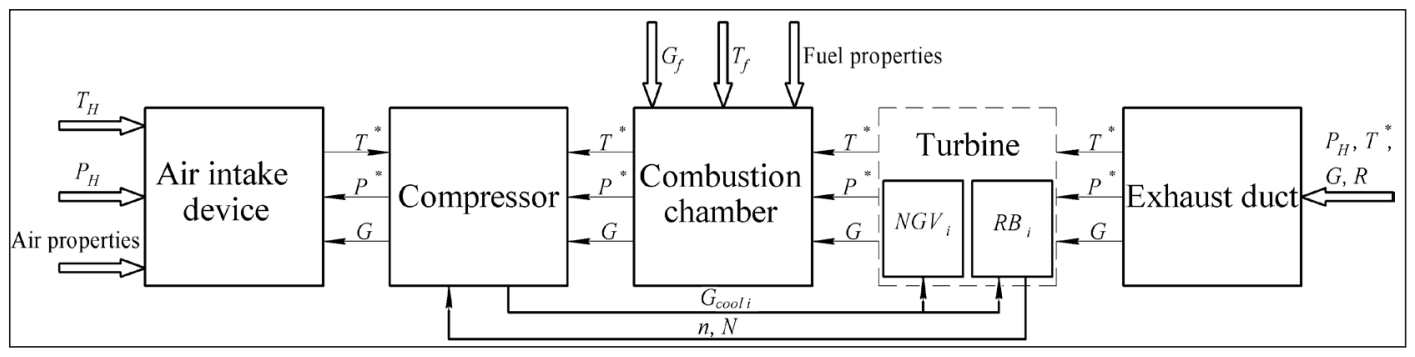

( $N G V_{i}$ - the i-th stage of nozzle guide vane; $R B_{i}$ - the $\mathrm{i}$-th stage of rotor blades)

Fig. 3. MM block-scheme

At the present $\mathrm{MM}$, turbine design is carried out on a pitch diameter according to the given geometric dimensions of the wheel space. It is performed by using gas dynamics equations based on the principles of conservation of mass, energy and, momentum. That allows it to be related to second-level models. The model structure is described in detail by Chobenko et al. [23].

In order to solve the problem in the MM, it is necessary to identify the variable and controllable engine parameters and to determine objective functions.

The controlled parameters are the most important predicted characteristics of the engine measured during the experiment. In this case the following parameters are selected: electrical power, engine inlet airflow, fuel gas consumption, total inlet pressure losses, total compressor outlet pressure, total air compressor outlet temperature, total turbine exhaust gas temperature (total 8 parameters). When solving the identification problem, non-symmetrical ranges of controllable parameters variation were specified based on the a-priori information within the measuring equipment accuracy limits (measurement errors).

The variable parameters among the total number of input data are the following: compressor characteristics modelling coefficients, throat dimensions of turbine nozzle assemblies and rotors, proportionality factors of total pressure losses in the air inlet and gas exhausted systems as well as in the combustion chamber, relative quantity of cooling air in the turbine blade rings and blade rims as well as energy loss factors in them. The number of variable parameters is 48 . The variable parameters were assigned non-symmetrical measurement ranges depending on their type (geometrical and thermo-gas-dynamical) and the available a-priori information.
The objective functions (identification criteria) are represented by the values of the above-listed controllable parameters determined on MMs the variation range of which is determined based on the results of the direct measurements of flow parameters along the engine flow path and received during bench tests.

In this case the identification problem is that of minimizing a set of objective functions (identification criteria). In the process of solving it for each controllable parameter under study, the divergence of values received based on the engine test and MM prediction results in the specified range of deviations is minimized (no more than 1.5\%).

When solving the problem, the multi-criteria optimization algorithm is used. It is available in the SP Optimum. This algorithm combines stochastic methods with directed search methods. It allows avoiding inlet of weighting coefficients for specified quality criteria and further convolution into additive criteria. That makes it possible to find the best values for every specified criteria of identification.

The block diagram for solving the identification problem is shown in Fig. 4.

The identification was performed in two stages. At first, the problem was solved for the maximum power mode. At that there are 8 controllable and 48 variable parameters.

In the maximum power mode (the first stage) the identification problem was solved in three settings:

- identification with zero deviations of the variable parameters at the initial point;

- identification problem solving with deviations of the variable parameters in the middle of the range at the initial point;

- identification with maximum deviations of the variable parameters at the initial point. 


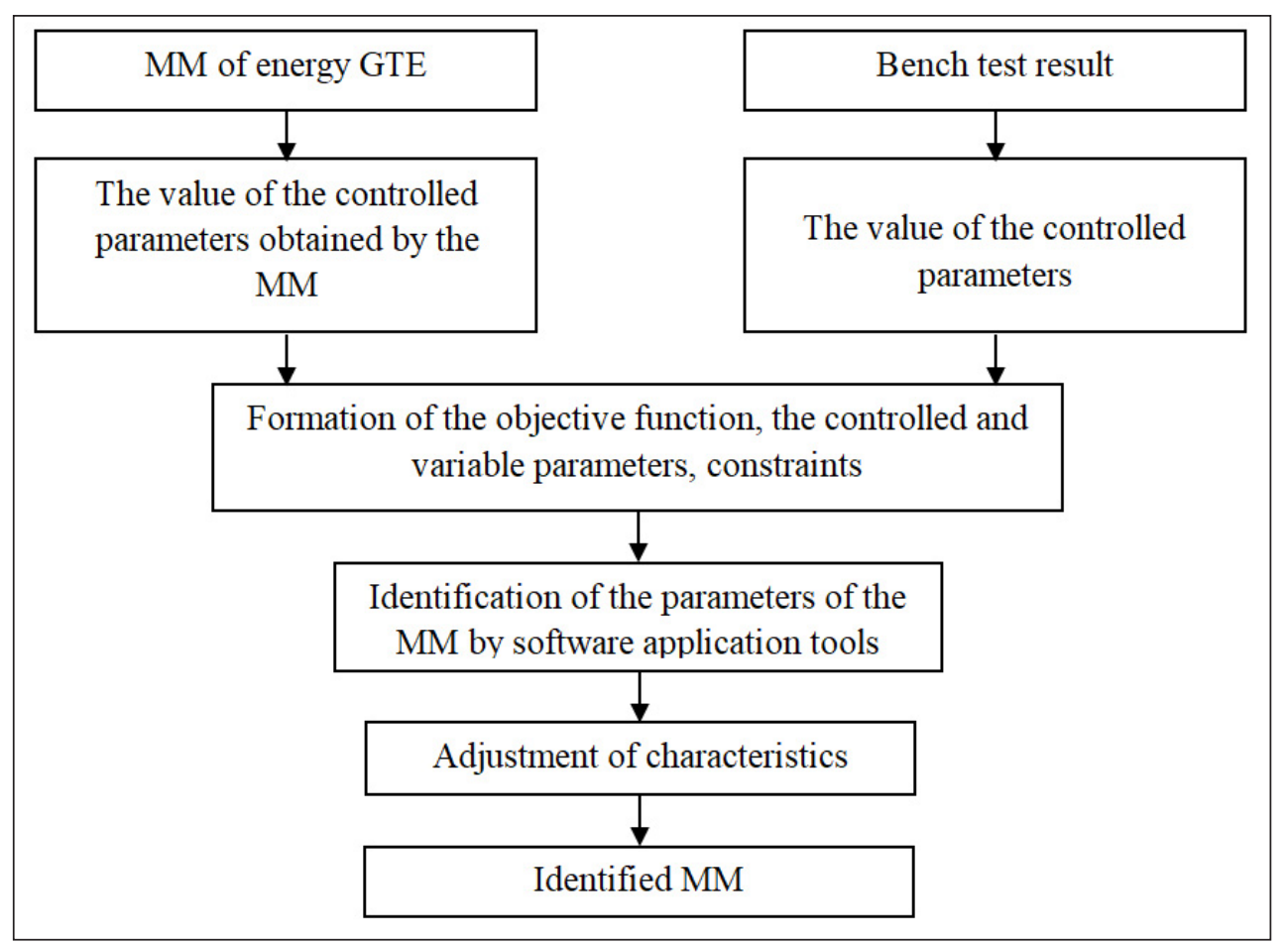

Fig. 4. Block-diagram of the identification algorithm

The decision on the identification results being satisfactory, in addition to that on the convergence of the problem with the required accuracy, was taken based on the comparison of the obtained results with MM manually identified by SE GTRPC "Zorya"-"Mashproekt" specialists taking into account the additional data received in the testing process. (air bleeding/return in engine cooling system, results of experimental determination of discharge characteristics of the turbine nozzle assemblies).

The results of solving the MM identification problem of GTE functioning for the maximum power mode are given in Table 2.
Taking into account that in MM the amount of the total inlet and outlet pressure losses, hydraulic losses in the combustion chamber, as well as values of cooling air bleeding/return are the functions of the engine parameters (depend on the mode of its operation). Therefore, after the parameters had been balanced in the maximum power mode, it was decided to convert correcting coefficients of these variable values to constant after solving the identification problem in lower modes. In addition, the following geometric parameters which did not vary depending on the GTE operation mode were converted to constants: the throat dimensions of turbine

Table 2. Identification problem solution result in the maximum power mode

\begin{tabular}{ccc}
\hline Controllable parameter & Set deviation, $\%$ & Received deviation, $\%$ \\
\hline Electrical power at the electric generator terminals & \pm 1 & -0.008 \\
\hline Air flow rate through the engine & $-0.5 \ldots 1$ & -0.336 \\
\hline Fuel gas consumption $\ldots 1.4$ & 1.381 \\
\hline Total inlet pressure losses & \pm 1.4 & -0.064 \\
\hline Total compressor outlet air pressure & $-0.4 \ldots 0$ & 0.186 \\
\hline Total air compressor outlet temperature & $0 \ldots 0.4$ & -0.008 \\
\hline Total turbine exhaust gas pressure & $-0.5 \ldots 2$ & 0.104 \\
\hline Total turbine exhaust gas temperature & $0 \ldots 0.4$ & -1.008 \\
\hline
\end{tabular}


nozzle assemblies and rotors. This approach allowed reducing number of variable parameters to 19 , thereby reducing the time to solve the problem of identification. At that, the total number of model input data was not changed.

At the next stage, the identification problem for each of the modes was solved. Because the identification of engine component mathematical model was performed for each experimental point that resulted in a number of adequate MMs being obtained with corresponding set of modelling coefficients for particular points of the throttle curve. At that, the values of the same variable parameters under various modes differed from each other.

Taking into account that the main aim of the identification is the creation of an adequate adequate mathematical model making it possible to receive the information over the entire range of engine operating modes, the next step is to correct MM by supplementing it with analytical dependences for modelling coefficients depending on engine operating mode.

For this, the variations of every correcting coefficient (variable parameters) on the total compressor pressure ratio (CPR) are obtained in numerical and graphical form. These variations can be approximated by the available in the SP Optimum function of selecting the best approximated dependence among 36 equations. The co- efficients of these dependences regression are determined by the least square method. All 36 approximation equations are ranked by the value of the determination coefficient $\left(R^{2}\right)$, which is one of the criteria of approximation quality [24].

The higher $\mathrm{R}^{2}$ value the higher the quality of experimental data approximation for the specified function. The decision on the final choice of approximated dependence is presented to a designer.

Below, the analytic approximated dependences for two of 19 coefficients of modelling and relative coefficients of determination are given as an example.

$$
\begin{aligned}
& \xi_{N A 1}=\frac{1}{\mathrm{CPR}} \cdot(1.383578036 \cdot \\
& \exp (-0.173323412 \cdot \mathrm{CPR})-1), \\
& R^{2}=0.9884
\end{aligned}
$$

where $\xi_{N A 1}$ - additional losses in the first nozzle apparatus, $\mathrm{CPR}$ - compressor pressure ratio.

$\eta_{C}=-0.6134 \cdot \mathrm{CPR}^{3}+32.022 \cdot \mathrm{CPR}^{2}-$ $533.66 \cdot \mathrm{CPR}+2719.1, \quad R^{2}=0.9865$.

where $\eta_{C}$ - combustion efficiency in the combustion chamber.

Figs. 5 and 6 show the diagrams of variance of the same coefficients before and after approximation.

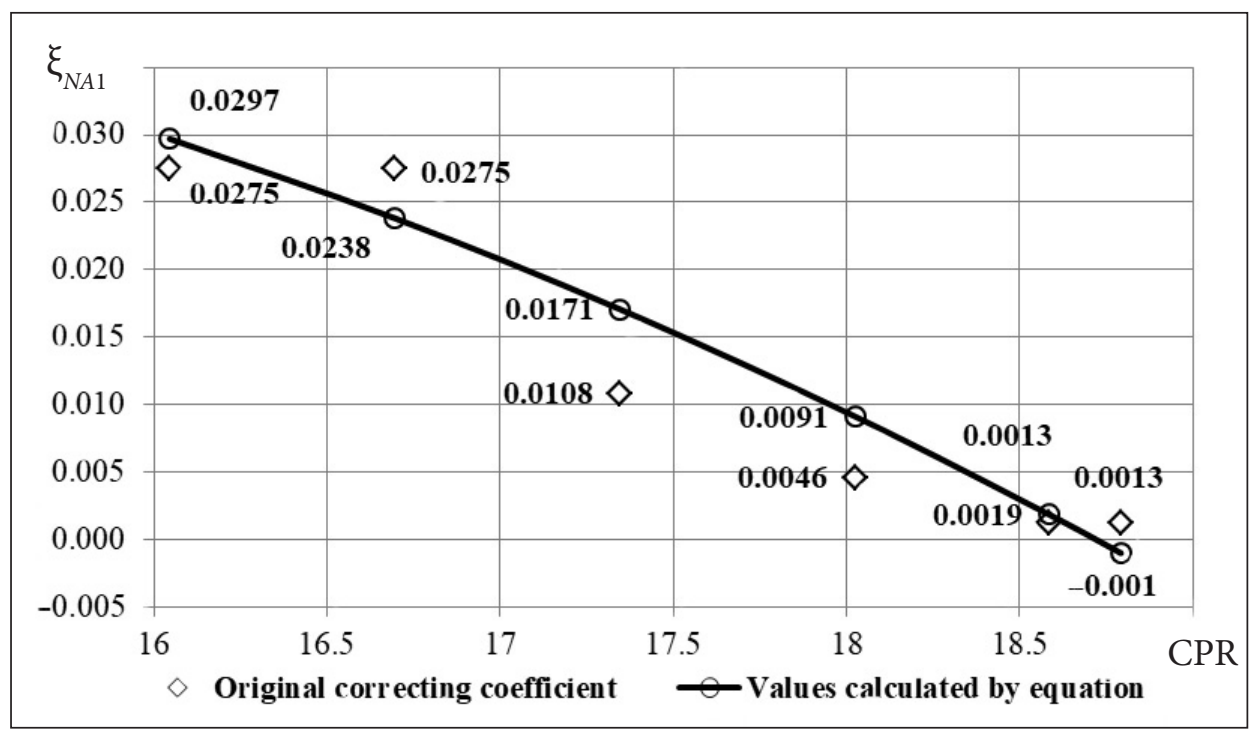

Fig. 5. Dependence of additional losses of the first stage turbine nozzle assembly $\left(\xi_{N A 1}\right)$ on compressor pressure ratio (CPR) 


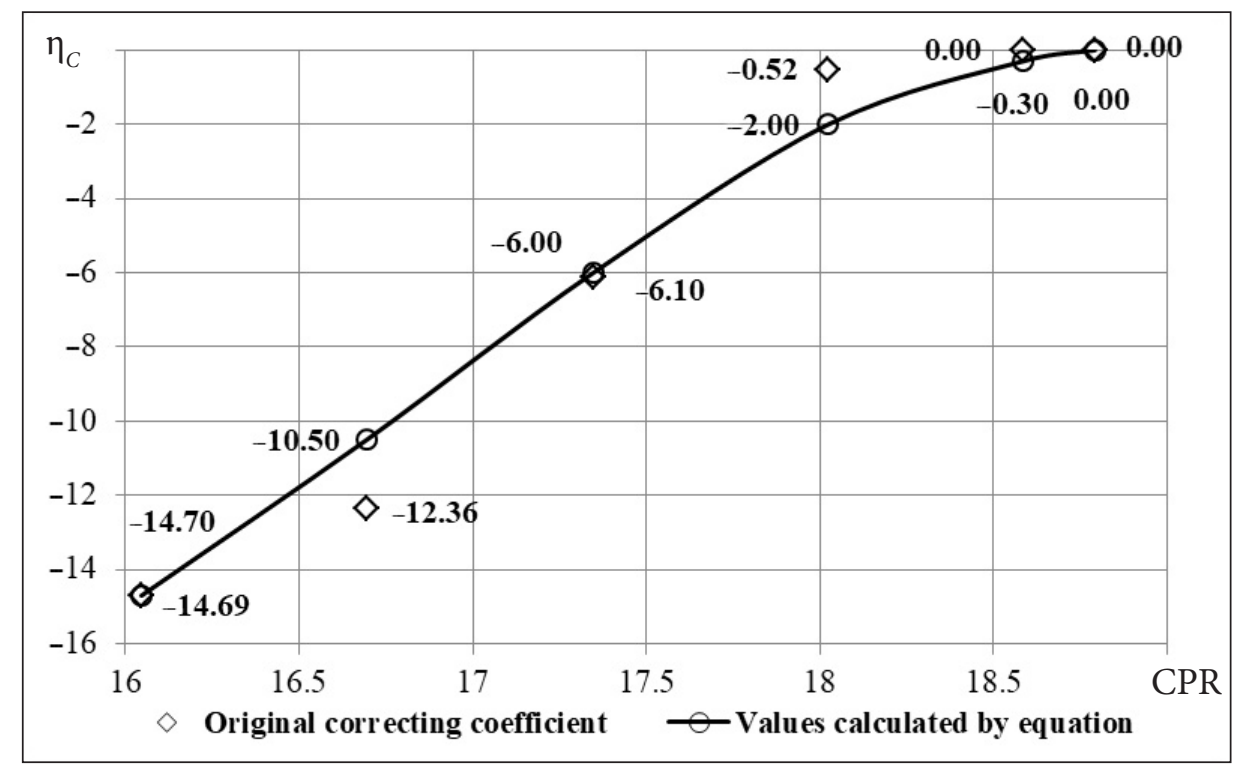

Fig. 6. Combustion efficiency ratio $\left(\eta_{C}\right)$ dependence on compressor pressure ratio (CPR)

After selecting dependences they were contributed to the model structure, thereby the structural-parametrical identification was performed. Obtained MM of GTE functioning showed a deviation of calculation magnitudes from experimental data no more than $1.4 \%$. Figure 7 show the results of GTE parameters calculation by means of MM identification in comparison with experiment results corrected to standard conditions.

\section{CONCLUSIONS}

The article presents the results of the non-linear component MM identification for the power-generating GTE functioning detailing the turbine flow path calculation to the level of blade rows without model linearization (without its level lowering) obtained using the SP Optimum.

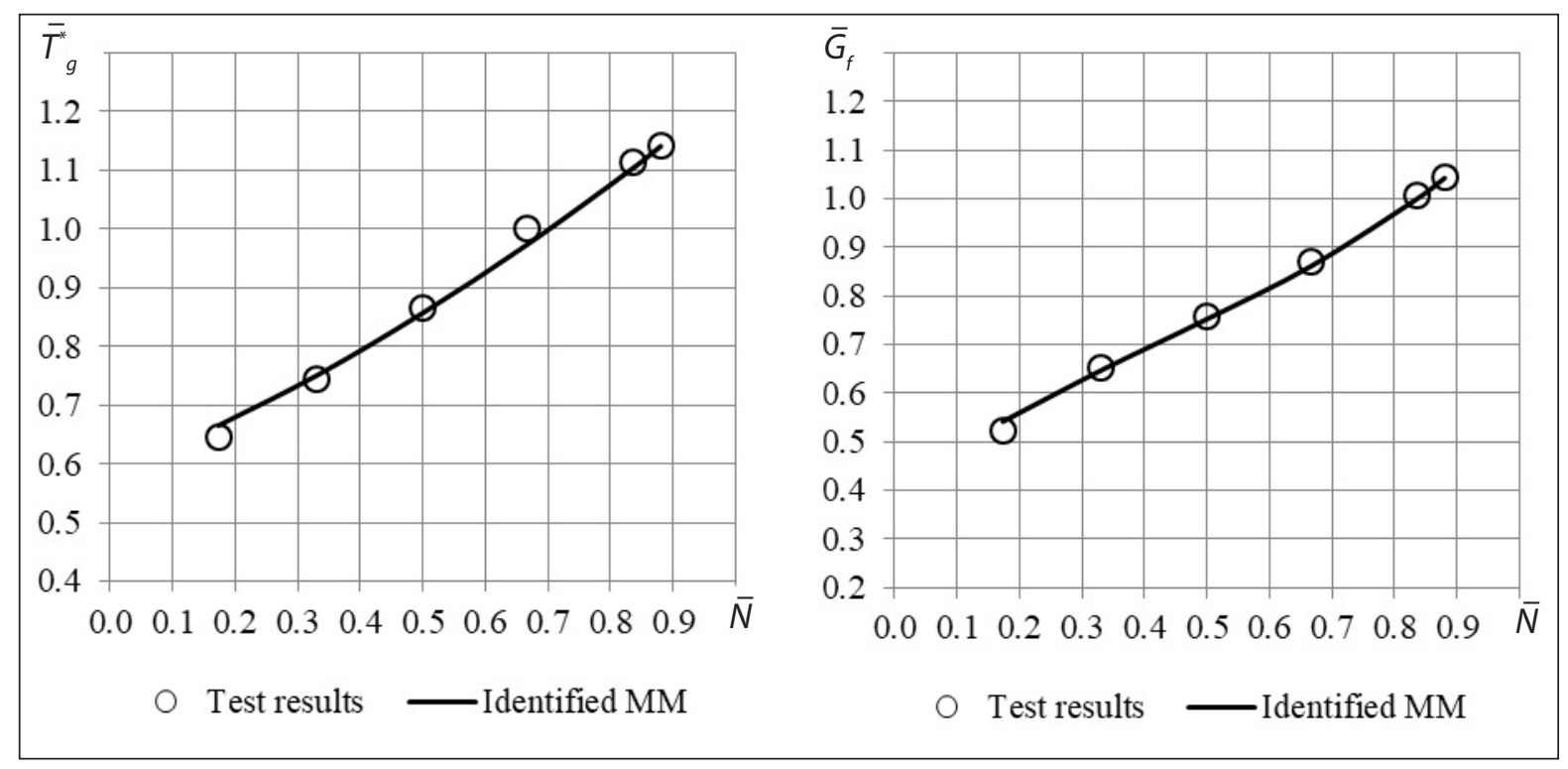

Fig. 7. a - GTE exhaust gas temperature $\left(-T_{\Gamma}^{*}\right)$ dependence on power at the generator terminals $(-N)$ in relative terms; $b-$ Fuel consumption $\left(-G_{T}\right)$ dependence on power at the generator terminals $(-N)$ in relative terms 
The suggested approach for solving the problem of identification of component mathematical model for power-generating GTE functioning through GTE operating modes (convert correcting coefficients of some numbers variable values to constant after solving the identification problem in the maximum power mode) allows reducing the number of variable parameters under the modes lower that the maximum one. The same allows reducing the time of identification.

The comparison of parameters obtained from the experimental simulation using the identified MM with the results of bench tests showed a deviation of the calculation results from experimental data no more than $1.4 \%$. The presence of adequate model will allow reducing the quantity of full-scale tests replacing them with calculated studies and thereby reducing energy consumption for their performing. As well the GTE development terms are reduced.

The obtained results indicate the efficiency of using SP Optimum at solving the problem of identifying MM GTE based on the bench tests results. The suggested approach allows solving the problems of MM identification for power-generating GTEs with a large number of variables. It can be used to create new power-generating gas turbine engines. Its use allows reducing the labour intensity and time of identification process.

Received 22 October 2020 Accepted 12 November 2020

\section{References}

1. Vasilyev B. P., Koval V. A., Kanakov V. V., Pavlenko G. V., Romanov V. V. Osnovy proyektirovaniya gazoturbinnykh dvigateley i ustanovok. Kharkov. 2005. 375 p. (Russian).

2. Shen J., Masiulaniec K. C., Afjeh A. A. Turbojet engine simulation using dymola. Collection of Technical Papers - AIAA/ASME/SAE/ASEE. 42nd Joint Propulsion Conference 2006. Vol. 6. P. $4760-4774$.

3. Gomes K. J., Masiulaniec K. C., Afjeh A. A. Performance, usage, and turbofan transient simulation comparisons between three commercial simulation tools. Journal of Aircraft. 2009. Vol. 46. No. 2. P. 699-704.
4. Kim S., Pilidis P., Yin J. Gas Turbine Dynamic Simulation Using Simulink. SAE Technical Paper. 2000-01-3647. 2000.

5. Kong C., Roh H., Lim K. Steady-state and transient simulation of turboprop engine using SIMULINK model. ASME Turbo Expo. 2003. Vol. 3. P. 151-161.

6. Traverso A. TRANSEO code for the dynamic performance simulation of micro gas turbine cycles. ASME Turbo Expo. 2005. Vol. 5. P. 45-54.

7. Pilet J., Lecordix J., Garcia-Rosa N., Barenes R., Lavergne G. Towards a fully coupled component zooming approach in engine performance simulation. ASME Turbo Expo: Turbine Technical Conference and Exposition. 2011. Vol. 1. P. 287299.

8. Kurzke J. GasTurb 12. Design and Off-Design Performance of Gas Turbines Available at: http:// www.gasturb.de/manual.html

9. Kurzke J. About Simplifications in Gas Turbine Performance Calculation. Proceeding of ASME Turbo Expo 2007: Power for Land, Sea and Air - Montreal, Canada (GT2007-27620). 2007. $9 \mathrm{p}$.

10. DePlanchet C. P., Frederick R. A. Application of the GECAT Software for Instruction in Gas Turbine Propulsion Analysis. 36th AIAA/ASME/ SAE/ASEE Joint Propulsion Conference and Exhibit, 24-28 July 2000. Las Vegas, NV, U.S.A. https:// doi.org/10.2514/6.2000-3893

11. GSP 11 User Manual. Available at: http://www. gspteam.com

12. Morozov S. A. GRAD software package - gasdynamic calculations of aircraft engines. Aerospace technology and equipment. Collected reports of the scientific practical conference. Kazan: Kazan State Technological University. 2003. P. 190-196. (Russian).

13. Tkachenko A. Yu., Filinov E. P., Osapyuk Ya. A. Gas turbine engine parameters optimization at the stage of conceptual design. Samara: Samara State Aerospace University. 2018. Vol. 22 Ch. 2(80). P. 64-72. (Russian).

14. Apostolidis A., Sampath S., LaskaridisvP., Singh R. Webengine - A WEB-based gas turbine performance simulation tool. ASME Turbo Expo. 2013. Vol. 4. 11 p. https://doi.org/10.1115/GT201395296 
15. Khustochka A. N., Kalyuzhny I. A. Mathematical model of the AI-450M turboshaft gas turbine engine. Proceedings of the international congress engine builders. Aerospace Engineering and Technology, Kharkov: "KhAI". 2010. Vol. 8(75). P. 99102. (Russian).

16. Khustochka A. N. Identification of the mathematical model of the engine AI-25TL with its modernization. Aerospace Engineering and Technology, Kharkov: “KhAI”. 2004. Vol. 8(16). P. 151-154. (Russian).

17. Avgustinovich V. G., Kuznetsova T. A., Kurakin A. D., Fatykov A. I., Yakushev A. P. Linear adaptive on-board engine model as way to enhance full authority digital engine control. Bulletin of the PNRPU. Aerospace Engineering. 2015. Vol. 42. P. 47-60. doi: 10.15593/2224-9982/2015.42.04

18. Ji X., Gu Ch., Liu H., Xie W. Performance calculation of a three-shaft gas turbine: experiment evaluation and analysis. Proceedings of ASME Turbo Expo 2013: Turbine Technical Conference and Exposition GT2013. Vol. 2. 9 p. https://doi. org/10.1115/GT2013-94490

19. Zhu W., Ren X.-D., Li X.-S., Gu C.-W. Analysis and Improvement of a Two-Stage Centrifugal Compressor Used in an MW-Level Gas Tur- bine. Applied Sciences. 2018. Vol. 8. 1347. 20 p. doi:10.3390/app8081347

20. Hosseini M., Sun Zh., Xiao He X., Zheng X. Effects of Radial Gap Ratio between Impeller and Vaned Diffuser on Performance of Centrifugal Compressors. Applied Sciences. 2017. Vol. 7. 728. doi:10.3390/app7070728

21. Hou J., Ji X., Gu Ch., Liu H. Performance Analysis of a MW Level Gas Turbine's Power Turbine with a Variable Area Nozzle and an Asymmetrical Exhaust Nozzle. Journal of Engineering for Thermal Energy and Power. 2012. Vol. 6. P. 11-23.

22. Tarelin A. A., Annopolskaya I. E., Antiptsev Yu. P., Parshin V. V. Information-instrumental system for solving optimization and identification problems in the design and development of power plants. Bulletin of the NTU 'KhPI'. 2012. No. 8. P. 17-25. (Russian).

23. Chobenko V. N., Paliyenko R. V., Lyutikov A. L. Mathematical model of a single-shaft D045 GTE. Eastern-European Journal of Enterprise Technologies. 2013. Vol. 3. No. 12(63). P. 18-21. (Russian).

24. Tarelin A. A., Antiptsev Yu. P., Annopolskaya I. E. Fundamentals of the theory and methods for creating an optimal last stage of steam turbines. Kharkiv. 2001. 224 p. (Russian). 
Anatoly Tarelin, Alexander Lyutikov,

Iryna Annopolska

VIENO VELENO ENERGETINIŲ DUJŲ

TURBINŲ SKAITINIS MODELIS

\section{Santrauka}

Dujų turbinų variklių projektavimo ir plètros procesai betarpiškai siejasi su skaitinių modelių, atkartojančių šiluminių variklių veikimo procesus, panaudojimu. Vienas iš būdų patikrinti tokius modelius - skaitinio modeliavimo rezultatu palyginimas su eksperimentiniais rezultatais.

Šiuolaikinių energetinių dujų turbinų šiluminių variklių skaitinių modelių sudarymas reikalauja patirties ir laiko, nes būtina eksperimentiškai nustatyti pagrindinius parametrus, atsižvelgiant ị daugelị bandymų metu nekontroliuojamų parametrų. Sudarant skaitinius modelius ir siekiant sumažinti darbo sąnaudas, naudojami specialūs prognozavimo metodai ir priemonès. Tyrimo tikslas - nustatyti struktūrinius-parametrinius funkcionalumo ryšius tarp realios turbinoje tèkmès ir skaitinio modelio prognozavimo, įvertinant srauto dinamiką darbo mentèse, rezultatų, kad būtų sukurtas tinkamas ir siekiamo tikslumo dujų turbinos skaitinis modelis. Tikslui pasiekti buvo išspręstos šios problemos: kintami ir kontroliuojami srauto parametrai, charakteristikos, taip pat kitimo diapazonai buvo parinkti pagal skaitinio modelio įvesties duomenų imtị, apibrèžtos tikslinès funkcijos; atliktas skaitiniu būdu nustatytų parametrų palyginimas remiantis bandymų rezultatais modeliuojant eksploatacinius režimus; nustatytos analitinès koreliacijų koeficientų priklausomybès; sudarytas struktūrinis-parametrinis skaitinis modelis. Gautų rezultatų naujumą i̇rodo aprašomas antrojo lygio netiesinio dujų turbinos matematinio modelio sukūrimas naudojant „Optimum“ programinę ịrangą. Straipsnyje pateikiamas metodologinis matematinio modelio parametrų identifikavimo metodas, jis leidžia sumažinti kintamųjų parametrų skaičių esant mažesniems nei maksimaliems eksploatavimo režimams. Tai rodo, kad sukurtas skaitinis modelis leidžia prognozuoti energetinių dujų turbinų parametrus ir charakteristikas darbo režimų metu su ne didesne nei 1,4\% paklaida, palyginti su eksperimentiniais duomenimis. Šis skaitinis modelis leis sumažinti energijos įrenginio vertinimo laiko sąnaudas ir padidins tobulinimo kokybę.

Raktažodžiai: matematinis modelis, nustatymas, dujų turbinos, kintami parametrai, kontroliuojami parametrai 